\title{
COMMUNICATIVE LANGUAGE TEACHING AND ITS MISCONCEPTIONS ABOUT THE PRACTICE IN ENGLISH LANGUAGE TEACHING (ELT)
}

\author{
Sri Diana \\ Akademi Teknik Industri Makassar, Kementerian Perindustrian RI \\ Address: Jln. Sunu No. 220, Makassar 60236 \\ E-mail: sridiana12@gmail.com
}

\begin{abstract}
Abstrak
Communicative Language Teaching (CLT) telah diterima sebagai salah satu metode pengajaran oleh banyak pengajar bahasa karena fokus utamanya pada peningkatan kemampuan komunikasi pelajar. Tulisan ini bertujuan menjelaskan tentang Communicative Language Teaching, kekeliruan penerapan dalam pengajaran Bahasa Inggris dan faktorfaktor yang menyebabkan guru-guru keliru dalam penerapannya. Artikel ini memperlihatkan empat persepsi keliru tentang penerapan Communicative Language Teaching: Kemampuan komunikasi, peran guru dalam kegiatan komunikasi, kefasihan dan ketepatan sebagai tujuan utama serta teknik pengajaran. Kemudian tulisan ini juga memaparkan tiga alasan yang kemungkinan sebagai penyebab terjadinya kesalahan persepsi dalam penerapan CLT: para guru tidak memiliki pelatihan dan sumber daya yang memadai.
\end{abstract}

Kata-Kata Kunci: CLT (Communicative Language Teaching), Misconception, Misinterpretation, ELT (English Language Teaching), Praktek.

\begin{abstract}
Communicative Language Teaching (CLT) has been accepted as one of the teaching methods by numerous language teachers due to its major focus on developing learners' communicative competence. This paper aims to describe communicative language teaching, misinterpretations about its practice and the factors leading to teachers' misconceptions. It shows four misinterpreted beliefs of the implementation of communicative language teaching: communicative skills, teacher's role in communicative activities, fluency and accuracy as the main goals and teaching techniques. It then presents three reasons that might lead to teachers' misinterpretations concerning the practice of CLT. Teachers do not have enough training and adequate resources.

Key Words: CLT (Communicative Language Teaching), Misconception, Misinterpretation, ELT (English Language Teaching), Practice.
\end{abstract}




\section{INTRODUCTION}

The recognition of English in the world has impacted English language teaching worldwide. Various teaching methods have come into the current trend and then disappeared. Without doubt, the more people want to learn English, the more variety of needs come into view. The more variety of needs come out, the more new approach or method in English language teaching required. In other words, learners have different purposes in learning English. Therefore, English language teaching should move forward in order to keeping up with the change. As can be seen, in the past fifty years alone, English language teaching has gone through a rapid change of transitions in its methodology, from grammar translation method to direct method, to audiolingualism, and to other variations (Leung, 2005). In other words, this change takes places in order to accommodate various needs of learners. Additionally, the most important transition in English language teaching has taken place through a collection of practices, materials, and belief about teaching and learning that are known by many different names, for instance, communicative methodology, communicative language teaching, and communicative approach (Richards and Rodgers, 1986). Thus, concerning to accommodating learners' needs many language experts and English educators have been working seriously in finding the best way to teach English. That is why until now English teaching methodology is still going through another transition.

Above all, Communicative Language Teaching (CLT) has been accepted as an effective approach by many language educators due to the major focus on developing learner ability to use the language appropriately in context. Among all methods used and practiced so far, CLT has been considered as the best practice in English language teaching (ELT) because it offers 'communication' means enabling learners to develop their communicative ability (Power, 2003). Similarly, according to Nunan (1999) "Communicative language teaching has brought the most significant change into the practice of English language teaching". Therefore, many educational and language institutions have adopted this approach into their ELT practices. However, according to Thomson (1996) there are still a number of misinterpretations among language teachers about the practice of CLT in English Language Teaching. He also mentioned that these misconceptions still keep on surviving; as a result, many teachers are difficult to see obviously the innovation that CLT has brought. Hence, this essay will discuss the four misconceptions about CLT in ELT. Then, it will discuss also the factors leading to teachers' misconceptions of such principles in ELT. There are four main beliefs of teaching in CLT that have been misinterpreted by teachers in ELT.

\section{COMMUNICATIVE COMPETENCE}

The first belief is learners are taught to be able to communicate in target language (Larsen-Freeman, 2000). Based on this first belief, students should be accommodated with five components of communicative language ability, that is, grammatical competence, discourse competence, sociolinguistic competence, and strategic competence. Grammatical competence includes learners' ability in spelling, pronunciation, vocabulary, word formation, and grammatical structure. Discourse competence requires learners to have the knowledge in dealing with the structure of longer texts in speech and a piece of writing. Sociolinguistic competence is the ability that learners should have in choosing the appropriate words or expressions in spoken or written context of situation. For instance, when learn how to write formal or informal ways of writing a letter and greeting someone. Strategic competence is the strategy of learners to keep the communication going on, even the language production is not perfect, for example, when learners unable 
to express what they want to say or they want to clarify misunderstanding (Beale, 2002; Brown, 2000; Leung, 2005; Richards and Rodgers, 1986). Generally speaking, this principle suggests that in teaching, teachers should not teach learners with one competence only, for instance, to master grammatical competence but also to apply the competence to communicate in the real context of life. However, in the implementation of CLT in the real teaching, teachers incorrectly adopt this principle by avoiding teaching grammar. Prabhu (1987) emphasized that "...grammar teaching is impossible because the knowledge that a speaker needs in order to use a language is simply too complex (cited in Thomson, 1996, p.10). This avoidance of teaching such competence is due to several factors. One of possible factors is teachers' lack of communicative competence in English. As a result, for teachers who do not have adequate communicative competence, there are two options offered. The first option is excluding teaching grammar in their lesson plan. In other words, teachers only emphasize on communicative activities without touching grammar at all. Another option is teaching grammar as separate part of lesson; for example, teaching imperative sentence then continues teaching the function of giving instruction such as making recipe. In this case, teachers can modify the imperative sentence with its function to give instruction in making recipe in meaning-based approach if only they had sufficient communicative competence and eagerness to put more effort in designing the lesson plan. Another reason is the lack of adequate teacher preparation. In this point, teachers do not want to spend more time to prepare the strategies or appropriate methods in teaching that competence. Sato and Kleinsasser (1999) stated that most teachers agree that communicative language teaching should be taught in a fun way and the preparation to make it fun is really timeconsuming. In other words, teaching grammar in communicative way needs to be prepared and requires lots of efforts. It is therefore, it is hard for school or language institutions that only has one teacher but has to teach many classes, because the teacher might think that this can be additional burden for him/her.

\section{THE ROLE OF TEACHERS IN COMMUNICATIVE ACTIVITIES}

The second belief is the role of teacher in communicative activities. In CLT, teacher is facilitator and guide, not the one who knows everything in classroom. This principle has replaced the traditional role of teacher as an information provider. Learners not only receive the knowledge transmitted by teachers but they should construct their own knowledge facilitated by teachers. The construction of meaning in getting knowledge is done through linguistic interaction with others (Brown, 2001). Additionally, the role of teacher sometimes could be partners for communication in the class with students (Littlewood, 1981, cited in LarsenFreeman, 2000). Similarly, according to Richards and Rodgers (1986) the role of teacher can be an independent member in the learning-teaching group. In the practice of CLT, this principle leads to two negative perceptions in classroom. The first negative perception is that teachers' inattention in monitoring learners' performance and activity in classroom. Some teachers think that after designing a lesson plan, which can facilitate and encourage learners practice their communicative skills in classroom, learners can construct their own meaning naturally and automatically. However, teachers forget that learners sometimes come from different background, which can create diversity in classroom. For example, some learners may feel comfortable and okay engage in activities without teacher supervision, but there are also learners who still need intense guidance from teachers, especially for the class that mixes abilities inside. Thus, despite of facilitating and guiding students, teacher's role also has to supervise or 
monitor her/his students' activities in class. Furthermore, some teachers also believe that they succeed in designing activities if students participate cheerfully and happily in completing all activities. Consequently, they use the noise in class as an indicator for the success of their activities they have created. The fact that if learners are interested in the activities they will engage in activities and leads to the achievement of the purpose of giving the opportunity to practice the communicative skills in classroom. In this case, teachers should eliminate their belief that the more noisy the class, the more interesting the activities. However, teachers have to ensure whether the noise is still in the right track that is participating and enjoying the activities in accomplishing the lesson objective. The other negative perspective is that the idea that learners should construct the meaning through their own understanding through interaction has made teachers believe that teaching explicitly is against the principle of CLT. Hence, teachers do not use the handouts, worksheets or other forms of practice, as they are afraid of making the lessons are not contextual and therefore not meaningful. On the other hand, teaching in fully implicit way also will not be advantageous for all learners for the reason that some of them may come from different cultural and linguistic background. These differences would lead to learners' different responses towards the pedagogical practice, which has been adopted by CLT in ELT. For instance, learners who come from the cultural background that believe teachers are the one who knows everything or fountain of knowledge will not be accustomed to the idea that learners should be independent and be able to construct their own meaning through linguistics interaction with others.
FLUENCY AND ACCURACY AS THE MAIN GOALS OF COMMUNICATIVE SKILLS

The third belief is fluency and accuracy should be the goals of communicative skills. According to Brown (2001) "sometimes fluency is more emphasized than accuracy in order to encourage learners to speak in the language expressively and naturally". Similarly, Finocchiaro and Brumfit (1983) stated that one of the major distinctive features of the audiolingual method and the communicative approach of CLT is that in the audiolingual method, accuracy is the primary goal while in CLT; fluency is the primary goal of teaching (cited in Richards and Rodgers, 1986). Due to fluency, most teachers in ELT have misinterpreted the focus of CLT. Teachers understand fluency as learners' capability in engaging themselves in communicative activities. Since teachers' understanding is to make learners engaged in communicative activities, teachers always try to motivate learners to use the language, especially in beginner English class. They believe that if learners have already had the courage to speak in the language, means all objectives of communicative activities can be achieved. In reality, fluency is not a matter of just talking in the language, fluency according to Fillmore (1979) included four abilities: the ability 'to talk without significant pauses for an extended period of time', the ability to show 'a mastery of the semantic and syntactic resources of the language', the ability to have 'appropriate things to say in a wide range of contexts', and the ability to 'creative and imaginative in...language use' (Cited in Brumfit, 1984, pp. 53-54). In other words, it can be said that fluency means learners have to apply all the required competences as discussed earlier in this essay. Additionally, teachers sometimes are unwilling to correct learners' mistakes during the conversation. Error correction has also been the most important cause of creating reluctant speakers in classroom. This can contribute to the failure 
of the practice of CLT in ELT. Nevertheless, the absence of error correction given by teachers will not affect on learners' fluency. Due to the error correction, there are some ways of giving feedback for learners, as error correction is also a vital tool to improve learners' competence in the language. As Board of Senior Secondary School Studies (1996, cited in Sato and Kleinsasser, 1999) mentioned that students can manage their own learning if teachers give them informative feedback. Error correction done when learners talk in the language, which teachers directly corrects the mistakes. Some teachers believe that this is a very effective way because learners will remember their mistakes. On the contrary, others prefer to give feedback after learners have finished the speaking activity, they consider if they interrupt the speaking, learners will not talk in the language naturally otherwise they are afraid of expressing their ideas. Therefore, teachers should be more selective in choosing the way they would correct learners' error in order to let learners convey their ideas freely and naturally. As stated by Brown and Nation (1997) in term of error correction teachers should consider whether the error is worth the interruption, and if it is, so the teacher should also think the appropriate ways of dealing with the errors.

\section{TECHNIQUES OF TEACHING TO SUPPORT AND ENCOURAGE LEARNERS TO ENGAGE IN COMMUNICATIVE ACTIVITIES}

The fourth belief is the techniques of teaching are designed to give students opportunities to involve in the pragmatic, authentic and functional use of language for meaningful purposes. Language forms are not the aim of study, but the components required to achieve those purposes (Brown, 2000; Brown, 2001). Therefore, teachers who claim themselves CLT followers should provide materials that include the four skills, that is, speaking, listening, reading, and writing to support and encourage learners to engage in communicative activities, not the skills in knowing the rules of grammar, memorizing patterns and meaning of words. Richards and Rodgers (1986) said "practitioners of CLT view materials as a way of influencing the quality of classroom interaction and language use. Materials thus have the primary role of promoting communicative language use"(p.79). Additionally, the use of authentic language materials is expected in order to solve the typical problem that learners are unable to transmit what they learn in traditional classes to the real situation outside the class. Also, using authentic materials can expose students to natural language in a variety of situation (Larsen-Freeman, 2000). Moreover, authentic language materials are potentially more interesting than texts, which have been specially contrived for language teaching purposes (Nunan, 1999).

Relating to supporting communication in classroom, there are two types of communicative activities that is 'functional communicative activity' and 'social interaction activity' (Littlewood, 1981). Functional communication activity means the completion of task such as comparing sets of pictures and finding similarities and differences etc. Social interaction activity refers to a social context that takes in conversation and discussion, dialogues, role-plays etc. So, in classroom, for example, teachers use an activity that can be done in pairs such as transactional task where there is information gap between two learners and they have to fill in that information gap. Liao (1996) asserted, "Information gap is the essence of communication" (p.15). Another activity can be used is group work. Learners can work together to solve a problem, to analyze the new language structures in a text, and to give them a chosen topic from the authentic material for instance, newspaper article to be discussed. It is believed that using pair work and group work to promote communicative activities in class are more useful and flexible for 
learners (Thomson, 1996). In addition, concerning to communicative activities, there are four purposes of giving learners communicative activities according to Littlewood (1981). The first purpose is to give them 'whole task practice' where learners can practice all the skills they learn in one communicative activity. The second purpose is to improve their motivation. This motivation is usually related to learners' purpose in learning English and most of them learn English in order to communicate English so it is hoped that the communicative activity they are engaged would motivate them to use the language. The third purpose is exposing them to natural learning. Unquestionably, communication is the natural process of language learning. Thus, the communicative activity whether inside or outside the classroom is an essential part of learning process. The last purpose is helping learners to create a context that supports learning. Communicative activity would help to enhance the relationship among learners and between learners and teachers. The reciprocal relationship established would support the learning process.

However, there are several interesting findings associated to the implementation of this principle in ELT. The vision that CLT focuses on aspects of language that enable learners to accomplish their purpose to communicate gives teachers understanding that speaking and listening are the most important skills that learners have to communicate. This leads to undesirable implications on CLT in classroom. On one hand teachers feel reluctant to teach reading and writing because these two skills are assumed difficult to be taught in communicative ways. On the other hand learners also feel that they do not really need to have reading and writing skills for the simple reason that their teachers seldom teach them those skills. In other words, teachers only put more emphasis on speaking and listening abilities and seldom introduce the importance of reading and writing abilities in the form of communicative activities. Equally, the activities that should promote communicative abilities such as pair work and group work in the forms of dialogue, discussion and games are seemed to be monotonous and tedious by learners. It is not because of the principle of CLT supporting the use of these communicative activities. Indeed, it is because teachers do not familiarize in designing a variety of activities can be used in class. In other words, those activities have no variation and for that reason learners are easily bored to be involved in the activities. Conversely, the blame cannot be put only into teachers because there several reasons might cause this problem. The first reason is teachers do not get enough training, so they do not have sufficient knowledge to be more creative in designing the tasks. The second reason is teachers do not have adequate resources to create various kinds of activities. The last reason and the most important one is most of developing countries have low standard salary for teachers so most of them try to find side jobs in order to fulfill their daily needs. Consequently, teachers always lack of preparation for teaching as they have limited time to prepare everything before coming to class. Undoubtedly, teachers' lack of preparation will result in low quality of teaching.

\section{CONCLUSION}

To sum up, it is true that there are several misconceptions about the practice of CLT by teachers in the classroom. It is also believed that those misconceptions are caused by internal and external factors. The internal factors that are from the teachers themselves, for instance, some teachers are reluctant to improve their professional skills in teaching and also teachers' lack of communicative competence, whereas the external factors may be in the forms of insufficient training given to teachers, inadequate resources for teaching, and the low salary from teaching. On the whole, the implementation of CLT in ELT needed to 
be improved in an inclusive way that requires the support and involvement of all people in the school or institutions where CLT approach has been applied.

\section{ACKNOWLEDGEMENTS}

We would like to thank the Journal Editor of Bahasa dan Sastra FPBS Universitas Pendidikan Indonesia for publishing this article, and also thank to those who have helped me to complete this article.

\section{REFERENCES}

Beale, J. 2002. Is communicative language teaching a thing of the past?. TESOL, 37 (1), 12-16.

Brown, H.D. 2000. Principles of Language Learning and Teaching. ( $4^{\text {th }}$ ed.). New York: Pearson Education.

Brown, H.D. 2001. Teaching by Principles: An interactive Approach to Language Pedagogy ( $2^{\text {nd }}$ Ed.). New York: Pearson Education.

Brown, R.S., \& Nation, P. 1997. Teaching Speaking: Suggestions for the Classroom. Retrieved June 10, 2013 from http://jaltpublications.org/tlt/files/97/jan/speakin g.html

Brumfit, C.1984. Communicative Methodology in Language Teaching. New York: Cambridge University Press.

Larsen-Freeman, D. 2000. Techniques and Principles in Language Teaching. $\left(2^{\text {nd }}\right.$ ed.). UK: Oxford University Press.

Leung, C. 2005. "Convivial communication: recontextualizing communicative competence". International Journal of Applied Linguistic, 15 (2), 119-143.
Liao, X. 1996. Tradition and Innovation: A New Way to Explore a TESOL Method. U.S: Office of Education Research and Improvement.

Littlewood, W. 1981. Communicative Language Teaching. New York: Cambridge University Press.

Nunan, D. 1999. Second Language Teaching \& Learning. Massachusetts: Heinle \& Heinle Publishers.

Power, T. 2003. The Appeal and Poverty of CLT. Retrieved June 11, 2013, from http://www.btinternet.com/ ted.power/ $\underline{\text { es10404.html }}$

Richards, J.C., \& Rodgers, T.S. 1986. Approaches and Methods in Language Teaching. USA : Cambridge University Press.

Sato, K., \& Kleinsasser, R.C. 1999. Communicative Language Teaching (CLT): Practical Understandings. The Modern Language Journal, 83 (4), 494-515.

Thomson, G. 1996. "Some misconceptions about communicative language teaching”. ELT Journal, 50 (1), 9-15. 
bahasa \& sastra, Vol. 14, No.1, April 2014 